\title{
Mass balances and life cycle inventory of home composting of organic waste
}

\author{
Andersen, Jacob Kragh; Boldrin, Alessio; Christensen, Thomas Højlund; Scheutz, Charlotte
}

Published in:

Waste Management

Link to article, DOI:

10.1016/j.wasman.2011.05.004

Publication date:

2011

Document Version

Peer reviewed version

Link back to DTU Orbit

Citation (APA):

Andersen, J. K., Boldrin, A., Christensen, T. H., \& Scheutz, C. (2011). Mass balances and life cycle inventory of home composting of organic waste. Waste Management, 31(9-10), 1934-1942.

https://doi.org/10.1016/j.wasman.2011.05.004

\section{General rights}

Copyright and moral rights for the publications made accessible in the public portal are retained by the authors and/or other copyright owners and it is a condition of accessing publications that users recognise and abide by the legal requirements associated with these rights.

- Users may download and print one copy of any publication from the public portal for the purpose of private study or research.

- You may not further distribute the material or use it for any profit-making activity or commercial gain

- You may freely distribute the URL identifying the publication in the public portal

If you believe that this document breaches copyright please contact us providing details, and we will remove access to the work immediately and investigate your claim 


\title{
MASS BALANCES AND LIFE CYCLE INVENTORY OF HOME COMPOSTING OF ORGANIC WASTE
}

\author{
J. K. Andersen, A. Boldrin, T. H. Christensen and C. Scheutz
}

Department of Environmental Engineering

Technical University of Denmark

Kongens Lyngby, Denmark

"NOTE: this is the author's version of a work that was accepted for publication in Waste Management journal. Changes resulting from the publishing process, such as peer review, editing, corrections, structural formatting, and other quality control mechanisms may not be reflected in this document. Minor changes may have been made to this manuscript since it was accepted for publication. A definitive version is published in Waste Management, vol 31, pp 1934-1942, doi: 10.1016/j.wasman.2011.05.004" 


\begin{abstract}
A comprehensive experimental setup with six single-family home composting units was monitored during one year. The composting units were fed with 2.6-3.5 kg organic household waste (OHW) per unit per week. All relevant consumptions and emissions of environmental relevance were addressed and a full life-cycle inventory ( $\mathrm{LCl}$ ) was established for the six home composting units. No water, electricity or fuel was used during composting, so the major environmental burdens were gaseous emissions to air and emissions via leachate. The loss of carbon (C) during composting was $63-77 \%$ in the six composting units. The carbon dioxide $\left(\mathrm{CO}_{2}\right)$ and methane $\left(\mathrm{CH}_{4}\right)$ emissions made up 51$95 \%$ and 0.3-3.9\% respectively of the lost $\mathrm{C}$. The total loss of nitrogen $(\mathrm{N})$ during composting was $51-68 \%$ and the nitrous oxide $\left(\mathrm{N}_{2} \mathrm{O}\right)$ made up $2.8-6.3 \%$ of this loss. The $\mathrm{NH}_{3}$ losses were very uncertain but small. The amount of leachate was $130 \mathrm{~L} \mathrm{Mg}^{-1}$ wet waste (ww) and the composition was similar to other leachate compositions from home composting (and centralised composting) reported in literature. The loss of heavy metals via leachate was negligible and the loss of $C$ and $N$ via leachate was very low $(0.3-0.6 \%$ of the total loss of $\mathrm{C}$ and $1.3-3.0 \%$ of the total emitted $\mathrm{N}$ ). Also the compost composition was within the typical ranges reported previously for home composting. The level of heavy metals in the compost produced was below all threshold values and the compost was thus suitable for use in private gardens.
\end{abstract}

Keywords: Compost quality, home composting, single-family, emissions, life-cycle inventory, greenhouse gases, organic household waste, mass flow analysis, substance flow analysis.

Abbreviations: EF, Emission Factor; GHG, Greenhouse Gas; GWP, Global Warming Potential; LCl, Life-cycle Inventory; MFA, Mass Flow Analysis; OHW, Organic Household Waste; SFA, Substance Flow Analysis; ww, wet waste. 


\section{Introduction}

Home composting (or backyard composting as it is sometimes called) is a waste management option for organic household waste (OHW) in a number of countries. Home composting is considered to be a horticultural recreational activity, but recently home composting has been considered as a potential major diversion route for $\mathrm{OHW}$ (Jasim and Smith, 2003) in order to comply with the European landfill directive (CEC, 1999). It is difficult to describe home composting as one single standard technology because the waste producer is also the processor and end-user of the compost (Jasim and Smith, 2003). The composting process is taking place in many different ways and with very different operational schemes, which is one of the reasons for the lack of scientific studies in this field. Home composting should not be seen as an alternative treatment option for all organic waste in a region, but instead as a supplementary solution. The potential of doing home composting is to provide a flexible, low-cost approach to waste management and facilitate sustainable recycling for individual home owners. However, it requires the active participation of a significant proportion of the home owners in a region to impact waste diversion rates. This could be obtained by promoting home composting on a municipal level.

The most obvious environmental advantage of doing home composting compared to centralised composting is the avoidance of collection and transportation of the organic waste. Another advantage that is relevant for both centralised and home composting is the production of compost, which could potentially be used in the garden as a soil improver and thereby substitute the use of less "green" soil improvers such as mineral fertilisers and peat in growth media. This could, however, also constitute a problem, if the produced compost is not of good quality (stable, mature and low heavy metal content). The main disadvantage of home composting is the emissions of greenhouse gases (GHGs) from the composting unit contributing to global warming. Another potential disadvantage of home composting is leachate production.

Some inventory data for home composting are found in the literature. Amlinger et al. (2008) focused on the GHG emissions from multi-family (high input) home composting. Colón et al. (2010) performed a full life-cycle inventory ( $\mathrm{LCl}$ ) of home composting, but in this case some of the inventory data were not included (leachate generation) or not well assessed (e.g. GHG emissions). In addition, the reported studies employed weekly additions of waste that was significantly higher that what a typical single-family household would add to the home composting unit. Amlinger et al (2008) added as much as $53 \mathrm{~kg}$ per week and Colón et al. (2010) as much as $18 \mathrm{~kg}$ per week, while it is estimated that for a Danish single-family household 1-4 kg of OHW could be composted per week (Petersen \& Kielland, 2003). Thus, there has until now been a lack of full LCls for single-family home composting.

LCls cover all consumptions and emissions of environmental importance (ISO, 2006). In this inventory study, only the direct emissions from the composting process have been included. This means that processes such as the production of the composting units, tools that were used during the process and transport associated with this were not 
addressed. The provided LCl form the basis for doing environmental assessments of home composting. The data include GHG emissions factors (EFs) that for the first time have been extensively investigated and quantified from single-family home composting. The method and the underlying data for these GHG EFs are given in Andersen et al. (2010a), where the experimental setup (the same as for this paper) is described in detail and the temperature development is presented for the entire composting period of one year.

The main objective of this study was to provide a comprehensive $\mathrm{LCl}$ of singlefamily (low input) home composting of organic household waste (OHW), based on comprehensive field studies, material flow analysis (MFA) and substance flow analysis (SFA). A secondary objective was to present the composition and assess the quality of the final compost product from home composting of OHW. The experimental setup was prepared with the intention of representing the most likely management of single-family home composting in Denmark.

\section{Methodology}

\subsection{Composting units}

The composting units (Humus/Genplast, 8230 Åbyhøj, Denmark) in this study are the most commonly used units for single-family home composting in Denmark, and they are offered to home-owners free of charge in some municipalities in order to promote home composting. The composting units are made of recycled polyethylene (PE) and polypropylene (PP) and weigh $22 \mathrm{~kg}$. They are cone-shaped with dimensions of $95 \mathrm{~cm}$ in height and $48 \mathrm{~cm}$ and $105 \mathrm{~cm}$ in diameter (top and bottom, respectively) giving a total volume of $0.32 \mathrm{~m}^{3}$. The composting units are equipped with a lid, an anti-fly net in the top to prevent flies from entering, a fine-masked steel net in the bottom to prevent rats and mice from entering and a hatch from where the mature compost can be collected. A picture and a schematic drawing of the composting units are presented in Andersen et al. (2010a).

A total of six composting units were used in the experimental setup and the difference in operation of the units was the difference in input waste and the frequency of mixing (see Table 1). The mixing consisted of manual agitation of the waste in the composting units with a mixing stick made of recycled PE and PP (delivered together with the composting unit). Units 1 and 2 were mixed every week and thus represented eager management, which is not considered to be a likely management approach. Units 3 and 4 were considered the most likely setup as they were mixed every sixth week, whereas Units 5 and 6 were not mixed at all, representing the "lazy" home composters. 
Table 1: Mixing frequency, amounts and moisture contents of input and output from the six composting units during the experiment. Parts of the table are taken from Andersen et al. (2010a). Amounts lost include gaseous emissions and leachate.

\begin{tabular}{|c|c|c|c|c|c|c|}
\hline $\begin{array}{l}\text { Composting } \\
\text { unit no. }\end{array}$ & $\begin{array}{c}\text { Mixing } \\
\text { frequency }\end{array}$ & $\begin{array}{l}\text { Amount } \\
\text { of input } \\
\text { ww }^{\mathrm{a}}(\mathrm{kg})\end{array}$ & $\begin{array}{l}\text { Moisture } \\
\text { content of } \\
\text { input (\%) }\end{array}$ & $\begin{array}{l}\text { Amount of } \\
\text { output } \\
\text { ww }^{\mathrm{a}}(\mathrm{kg})\end{array}$ & $\begin{array}{l}\text { Moisture } \\
\text { content of } \\
\text { output (\%) }\end{array}$ & $\begin{array}{l}\text { Amount } \\
\text { lost (\%) }\end{array}$ \\
\hline 1 & Every week & 184 & 71.4 & 84 & 75.1 & 55 \\
\hline 2 & Every week & 176 & 76.0 & 61 & 73.1 & 65 \\
\hline 3 & Every $6^{\text {th }}$ week & 146 & 73.0 & 52 & 69.4 & 64 \\
\hline $4^{b}$ & Every $6^{\text {th }}$ week & $151(+130)$ & 78.9 & 76 & 70.9 & 73 \\
\hline $5^{b}$ & No & $115(+20)$ & 63.8 & 59 & 67.1 & 56 \\
\hline 6 & No & 169 & 77.6 & 58 & 71.3 & 65 \\
\hline \multicolumn{7}{|c|}{$\begin{array}{l}\text { a ww, wet waste } \\
\text { b Additional organic household waste was composted in Unit } 4 \text { and } 5 \text { during the high load phase } \\
\text { (numbers in brackets show the input for the high load phase). }\end{array}$} \\
\hline
\end{tabular}

\subsection{Experimental outline and feedstock}

The experiments were designed to represent a steady-state situation in a home composting scenario. However, the experimental time frame of the study and the need of sampling of the matured compost demanded some compromising. The home composting units were initiated by a start-up period of three months in order to get a base-load of $\mathrm{OHW}$ in the composting units. The main experiments were performed during the composting period from May 2008 to May 2009. During the start-up period and the composting period, the composting units received waste every week. After the composting period, the units did not receive any waste for a period of three months in order to ensure maturation of the compost prior to sampling and characterization. The experimental period of Units 4 and 5 was extended for three months due to additional experiments with increased amounts of incoming waste. This is the reason for the elevated amounts of waste added in Units 4 and 5 (the extra amount is shown in brackets in Table 1). The effect of increased input has been described and discussed in Andersen et al. (2010a) and is not further addressed in this paper.

The input material consisted of OHW (food waste and small amounts of flowers and soil from the household) and low amounts of garden waste in order to provide structure. The $\mathrm{OHW}$ was delivered by families (volunteers from the Department of Environmental Engineering, Technical University of Denmark) approximately twice a week for one year. The total input per week per composting unit was 2.6-3.5 kg OHW and 0.12$0.15 \mathrm{~kg}$ garden waste on average during the composting period (see Table 1).

\subsection{Collection of data}

The $\mathrm{LCl}$ data were gathered from comprehensive field work campaigns. The emissions were primarily in gaseous form and via leachate. No water, electricity, fuels or other materials were used during composting. The output material was sampled and characterised in order to evaluate the quality of the product. 


\subsubsection{Sampling of solids}

Sampling of the input waste was performed before every addition of waste (approximately twice a week). Two samples (duplicates), each of $1 \%$ (mass) of the input, were taken from each waste delivery during one year of composting. The material was grab sampled to be as representatively as possible. The duplicates from each composting unit were pooled into a common sample which was kept in a freezer until the end of the experimental period. The samples were then thawed and dried before being shredded with a cutting mill (Retsch SM2000, Haan, Germany) and mass reduced with a riffle splitter (Rationel Kornservice RK12, Esbjerg, Denmark) to obtain $5 \mathrm{~g}$ laboratory samples for analysis. The cutting mill was equipped with heavy metal free coating (wolfram-carbon) on all wear parts. The cutting mill and riffle splitter were cleaned between samples to avoid cross contamination.

The compost was sampled systematically after the maturation period, according to the theory of sampling (Gy, 1998) and mass reduced from a total sample of 52-84 kg (see Table 1) to $5 \mathrm{~g}$ laboratory samples (according to Boldrin, 2009). Each of the samples was spread out on a clean plastic sheet in elongated one dimensional (1-D) piles. A plastic box $(40 \times 30 \mathrm{~cm})$ was used to separate cross-sectional slices of the lot and the slices were moved into two sub-piles. One of the sub-piles was chosen at random and processed further according to the same procedure, until a final sample of 8-10 kg was obtained. The samples were dried, shredded and reduced to $5 \mathrm{~g}$ laboratory samples in the same way as the input material. The outputs were more or less homogeneous in Units 1 and 2 due to the mixing during the composting period and the compost was sampled from the entire mass of output material. The outputs from Units 3 to 6 were on the other hand more heterogeneous (due to less mixing) and the output material was thus divided in two different samples: a "fresh" sample from the top part of the material and a "mature" sample from the bottom part of the material. The mature compost represents material that is ready for use in the garden and the quality of this fraction was thus assessed. For determination of the flow of material and substances, a weighted average of the parameters from the two samples was used. Dry ice $\left(\mathrm{CO}_{2}(\mathrm{~s})\right)$ was added during shredding of input and output material to ensure sufficient cooling capacity for keeping the waste solid and brittle.

Total Solids (TS) content of the input and output material was measured by drying the samples at $70^{\circ} \mathrm{C}$ for about 72 hours (or until constant weight). Volatile Solids (VS) content was measured as mass loss after heating the sample at $550^{\circ} \mathrm{C}$ for one hour. Two replicates per sample were sent for acid digestion and subsequent chemical analysis at a certified external laboratory (ALS Scandinavia AB, Luleå, Sweden). Similarly to the methods of Riber et al. (2007), samples were digested in a microwave digestion unit (with $5 \mathrm{ml} \mathrm{HNO}{ }_{3}+0.5 \mathrm{ml} \mathrm{H}_{2} \mathrm{O}_{2}$ ) (MARS 240/50, CEM Microwave Corporation, Matthews, NC, USA) and analysed with ICP-SFSM (ELEMENT, ThermoElectron, Finnigan MAT, Bremen, Germany) and ICP-OES (OPTIMA 5000, Perkin-Elmer, Wellesley, MA, USA). The analysed data were used as input parameters in the MFA and SFA modelling. All analysed parameters are presented in Table 2. 
Table 2: Composition of input material and compost from Units 1 and 3 and the range of all parameters in composting units 1-6. Some literature reference values are given for home composts.

\begin{tabular}{|c|c|c|c|c|c|c|c|c|c|c|}
\hline Parameter & Unit & $\begin{array}{l}\text { Input: } \\
\text { Unit } 1\end{array}$ & $\begin{array}{l}\text { Input: } \\
\text { Unit } 3\end{array}$ & $\begin{array}{c}\text { Input: } \\
\text { Range of } \\
\text { Unit 1-6 }\end{array}$ & $\begin{array}{l}\text { Compost: } \\
\text { Unit } 1\end{array}$ & $\begin{array}{c}\text { Compost: } \\
\text { Unit } 3 \\
\text { "Fresh"a }\end{array}$ & $\begin{array}{l}\text { Compost: } \\
\text { Unit } 3 \\
\text { "Mature" } \\
\text { a }\end{array}$ & $\begin{array}{l}\text { Compost: } \\
\text { Unit } 3 \\
\text { Weighted } \\
\text { average }\end{array}$ & $\begin{array}{l}\text { Compost: } \\
\text { Range of } \\
\text { Units 1-6 }\end{array}$ & $\begin{array}{l}\text { Compost: Literature } \\
\text { reference }\end{array}$ \\
\hline TS & $\%$ & $28.6 \pm 1.3$ & $27.0 \pm 2.3$ & $21.1-36.2$ & 24.9 & 28.2 & 30.6 & 29.9 & $24.9-33.0$ & $56^{\mathrm{b}}, 56.4^{\mathrm{c}}, 29.9-36.6^{\mathrm{e}}$ \\
\hline VS & $\%$ TS & $86.2 \pm 1.8$ & $71.9 \pm 8.5$ & $71.9-86.2$ & 62.3 & 62.2 & 45.2 & 50.4 & $45.2-62.3$ & $49^{b}, 48.0^{c}, 28.2-32.9^{e}$ \\
\hline C & $\%$ TS & $43.8 \pm 0.8$ & $38.2 \pm 3.9$ & $38.2-43.8$ & 35.6 & 36.2 & 24.7 & 28.2 & $24.7-35.6$ & $19-32^{d}$ \\
\hline H & $\%$ TS & $5.8 \pm 0.1$ & $5.0 \pm 0.6$ & $5.0-5.8$ & 4.2 & 3.9 & 2.6 & 3.0 & $2.6-4.2$ & - \\
\hline $\mathbf{N}$ & $\%$ TS & $1.8 \pm 0.03$ & $1.6 \pm 0.13$ & $1.6-1.9$ & 2.2 & 2.2 & 1.4 & 1.6 & $1.4-2.2$ & $\begin{array}{c}2.4^{\mathrm{b}}, 1.7^{\mathrm{c}}, 1.1-2.3^{\mathrm{d}}, 3.2- \\
3.5^{\mathrm{e}}\end{array}$ \\
\hline 0 & $\%$ TS & $34.5 \pm 0.8$ & $26.9 \pm 4.0$ & $26.9-35.0$ & 20.0 & 19.6 & 16.1 & 17.2 & $15.8-20.0$ & - \\
\hline $\mathbf{S}$ & $\%$ TS & $0.18 \pm 0.004$ & $0.18 \pm 0.03$ & $0.18-0.22$ & 0.37 & 0.38 & 0.33 & 0.34 & $0.33-0.38$ & - \\
\hline C:N & - & $24.3 \pm 0.09$ & $23.6 \pm 0.4$ & 21.7-24.7 & 16.0 & 16.8 & 18.0 & 17.7 & $15.8-18.0$ & $13.2-18.2^{d}$ \\
\hline Al & $\%$ TS & $0.24 \pm 0.03$ & $0.41 \pm 0.04$ & $0.24-0.41$ & 0.56 & 0.16 & 0.54 & 0.42 & $0.50-0.58$ & - \\
\hline $\mathrm{Ca}$ & $\%$ TS & $1.4 \pm 0.06$ & $2.7 \pm 0.27$ & $1.4-2.7$ & 3.5 & 7.0 & 4.8 & 5.5 & 3.1-6.8 & - \\
\hline $\mathrm{Fe}$ & $\%$ TS & $0.13 \pm 0.02$ & $0.25 \pm 0.10$ & $0.13-0.25$ & 0.37 & 0.09 & 0.35 & 0.27 & $0.35-0.41$ & - \\
\hline K & $\%$ TS & $1.4 \pm 0.01$ & $1.7 \pm 0.08$ & $1.4-1.8$ & 1.8 & 2.9 & 2.0 & 2.3 & $1.8-2.4$ & $1.3-1.9^{\mathrm{e}}$ \\
\hline $\mathrm{Na}$ & $\%$ TS & $0.41 \pm 0.01$ & $0.30 \pm 0.05$ & $0.25-049$ & 0.50 & 0.49 & 0.28 & 0.34 & $0.18-0.50$ & - \\
\hline $\mathbf{P}$ & \% TS & $0.26 \pm 0.005$ & $0.26 \pm 0.018$ & $0.26-0.29$ & 0.50 & 0.59 & 0.53 & 0.55 & $0.46-0.56$ & $0.6-0.7^{e}$ \\
\hline As & $\mathrm{mg} \mathrm{kg}^{-1} \mathrm{TS}$ & $0.69 \pm 0.08$ & $1.2 \pm 0.7$ & $0.7-1.2$ & 1.7 & 1.4 & 2.0 & 1.8 & 1.7-2.1 & - \\
\hline $\mathrm{Cd}$ & $\mathrm{mg} \mathrm{kg}^{-1} \mathrm{TS}$ & $0.13 \pm 0.004$ & $0.14 \pm 0.008$ & $0.13-0.16$ & 0.22 & 0.18 & 0.30 & 0.26 & $0.22-0.38$ & $0.3^{c}$ \\
\hline Co & $\mathrm{mg} \mathrm{kg}^{-1} \mathrm{TS}$ & $0.59 \pm 0.06$ & $1.3 \pm 0.05$ & $0.6-1.3$ & 1.7 & 0.42 & 1.8 & 1.4 & $1.6-3.0$ & - \\
\hline $\mathrm{Cr}$ & $\mathrm{mg} \mathrm{kg}^{-1} \mathrm{TS}$ & $6.4 \pm 0.4$ & $13.7 \pm 5.3$ & $5.9-13.7$ & 23.1 & 3.8 & 17.3 & 13.2 & $17.3-44.8$ & $9^{c}$ \\
\hline $\mathrm{Cu}$ & $\mathrm{mg} \mathrm{kg}^{-1} \mathrm{TS}$ & $11.3 \pm 0.07$ & $12.3 \pm 0.9$ & $10.2-14.0$ & 29.5 & 20.9 & 27.4 & 25.4 & 27.4-59.9 & $44^{c}$ \\
\hline $\mathrm{Hg}$ & $\mathrm{mg} \mathrm{kg}^{-1} \mathrm{TS}$ & $0.02 \pm 0.0002$ & $0.04 \pm 0.005$ & $0.02-0.05$ & 0.05 & 0.03 & 0.08 & 0.06 & $0.04-0.10$ & - \\
\hline$M n$ & $\mathrm{mg} \mathrm{kg}^{-1} \mathrm{TS}$ & $83.6 \pm 17.7$ & $96.0 \pm 4.0$ & 69-142 & 182 & 127 & 212 & 186 & $182-294$ & - \\
\hline Mo & $\mathrm{mg} \mathrm{kg}^{-1} \mathrm{TS}$ & $0.74 \pm 0.018$ & $0.80 \pm 0.01$ & $0.67-0.81$ & 1.4 & 1.9 & 1.6 & 1.7 & $1.4-1.9$ & - \\
\hline $\mathrm{Ni}$ & $\mathrm{mg} \mathrm{kg}^{-1} \mathrm{TS}$ & $2.3 \pm 0.12$ & $4.0 \pm 0.9$ & 2.3-4.1 & 6.7 & 2.5 & 5.6 & 4.7 & $5.6-7.9$ & $9^{c}$ \\
\hline $\mathrm{Pb}$ & $\mathrm{mg} \mathrm{kg}{ }^{-1} \mathrm{TS}$ & $3.7 \pm 0.47$ & $6.4 \pm 1.1$ & $3.7-8.8$ & 10.6 & 2.6 & 12.7 & 9.6 & $10.6-22.2$ & $28^{c}$ \\
\hline $\mathrm{Zn}$ & $\mathrm{mg} \mathrm{kg}^{-1} \mathrm{TS}$ & $34.2 \pm 1.5$ & $52.9 \pm 10.3$ & $34.2-52.9$ & 86.1 & 57.2 & 95.9 & 84.0 & 76.6-109 & $156^{\mathrm{c}}$ \\
\hline
\end{tabular}




\subsubsection{Leachate sampling}

Leachate from the home composting units was considered to be a minor contributor to environmental impacts. Unit 1 was, however, prepared with a leachate collection- and sampling system to estimate the quantity and quality of the leachate. A plastic base was inserted underneath the steel net close to the ground. The plastic base was equipped with a hole in the centre and a glass beaker was used to collect the leachate through the hole. The amount of leachate generated was recorded and collected every second day and sampled over two two-month periods (November-December 2008 and March-April 2009) in Unit 1. One pooled sample of the material from November-December 2008 was frozen and subsequently sent for chemical composition analyses at a certified external laboratory (ALS Scandinavia AB, Luleå, Sweden). A total of 18 parameters were analysed (Table 3).

Table 3: Composition of leachate from Unit 1 and other compositions of leachate from the literature.

\begin{tabular}{|c|c|c|c|c|c|}
\hline Parameter & Unit & $\begin{array}{c}\text { Unit } 1 \text { (This } \\
\text { study) }\end{array}$ & Loll, $1994^{\mathrm{a}}$ & $\begin{array}{c}\text { Fischer, } \\
1996^{b}\end{array}$ & $\begin{array}{c}\text { Wheeler et al., } \\
1999^{c}\end{array}$ \\
\hline pH & - & 8.9 & $5.8-8.6$ & $5-10$ & $6.0-8.8$ \\
\hline EC & $\mathrm{mS} \mathrm{m} \mathrm{m}^{-1}$ & 2480 & $940-2790$ & - & - \\
\hline $\mathrm{NO}_{2}^{-}-\mathrm{N}+$ & $\mathrm{mg} \mathrm{L}^{-1}$ & $<2.0$ & - & - & - \\
\hline $\mathrm{NO}_{3}^{-}-\mathrm{N}$ & $\mathrm{mg} \mathrm{L}^{-1}$ & $166 \pm 16.6$ & $<5-190$ & $1-25$ & - \\
\hline $\mathrm{NH}_{4}{ }^{+}-\mathrm{N}$ & $\mathrm{mg} \mathrm{L}^{-1}$ & $47 \pm 4.66$ & $50-800$ & $300-1200$ & - \\
\hline TOC & $\mathrm{mg} \mathrm{L}^{-1}$ & $2490 \pm 498$ & $5000-18000$ & - & - \\
\hline BOD & $\mathrm{mg} \mathrm{L}^{-1}$ & $3470 \pm 520$ & $\begin{array}{c}10000- \\
45000\end{array}$ & $10000-50000$ & $4-800$ \\
\hline COD & $\mathrm{mg} \mathrm{L}^{-1}$ & $9870 \pm 494$ & $\begin{array}{l}20000- \\
100000\end{array}$ & $15000-70000$ & $28-5500$ \\
\hline K & $\mathrm{mg} \mathrm{L}^{-1}$ & $6420 \pm 539$ & $1075-7280$ & $5000-15000$ & - \\
\hline $\mathbf{P}$ & $\mathrm{mg} \mathrm{L}^{-1}$ & $76.8 \pm 13.9$ & $50-150$ & $50-300$ & - \\
\hline $\mathbf{N}$ & $\mathrm{mg} \mathrm{L}^{-1}$ & $416 \pm 125$ & - & - & - \\
\hline As & $\mu g \mathrm{~L}^{-1}$ & $24.2 \pm 6.6$ & - & - & - \\
\hline Cd & $\mu \mathrm{g} \mathrm{L}^{-1}$ & $2.47 \pm 0.36$ & $10-200$ & $10-100$ & $<10-20$ \\
\hline $\mathrm{Cr}$ & $\mu \mathrm{g} \mathrm{L}^{-1}$ & $31.8 \pm 5.9$ & - & $10-200$ & $20-60$ \\
\hline $\mathrm{Cu}$ & $\mu \mathrm{g} \mathrm{L}^{-1}$ & $288 \pm 52$ & - & - & $40-300$ \\
\hline $\mathrm{Hg}$ & $\mu \mathrm{g} \mathrm{L}^{-1}$ & $0.28 \pm 0.047$ & - & - & - \\
\hline $\mathrm{Ni}$ & $\mu \mathrm{g} \mathrm{L}^{-1}$ & $87 \pm 16.1$ & $70-260$ & - & $30-200$ \\
\hline $\mathrm{Pb}$ & $\mu g \mathrm{~L}^{-1}$ & $99.4 \pm 17.3$ & $10-200$ & $10-200$ & $20-200$ \\
\hline \multicolumn{6}{|c|}{$\begin{array}{l}\text { a leachate from centralised composting of biowaste (mix of organic household waste and garden waste) } \\
{ }^{b} \text { leachate from centralised composting of source separated compostable material } \\
\text { c leachate from home composting of } 20-30 \% \text { kitchen waste, } 60-80 \% \text { garden waste and }<5 \% \text { other waste } \\
\text { (including paper }\end{array}$} \\
\hline
\end{tabular}




\subsubsection{Quantification of gaseous emissions}

The gaseous emissions were studied comprehensively throughout the entire year of composting as well as during the maturation period of an additional three months. A static chamber system was fixed to the composting units and the emissions were measured twice a week with a photo acoustic gas monitor (INNOVA 1312, Lumasense Technologies A/S, 2750 Ballerup, Denmark) as described in Andersen et al. (2010a). From the measurements, a total emission factor (EF) (in kg substance $\mathrm{Mg}^{-1} \mathrm{ww}$ ) for carbon dioxide $\left(\mathrm{CO}_{2}\right)$, methane $\left(\mathrm{CH}_{4}\right)$, nitrous oxide $\left(\mathrm{N}_{2} \mathrm{O}\right)$ and carbon monoxide $(\mathrm{CO})$ was calculated from each of the six composting units. In addition, a total global warming $\mathrm{EF}$ (in $\mathrm{kg} \mathrm{\textrm {CO } _ { 2 } -}$ equivalents (eq.) $\mathrm{Mg}^{-1} \mathrm{ww}$ ) was calculated using the global warming potentials given by the IPCC for $\mathrm{CH}_{4}(\mathrm{GWP}=25)$ and $\mathrm{N}_{2} \mathrm{O}(\mathrm{GWP}=298)$ (Solomon et al., 2007). The $\mathrm{CO}_{2}$ released in the process had previously been taken up by the plants/food and is considered to be biogenic (GWP=0) (Christensen et al., 2009).

The concentration of $\mathrm{NH}_{3}$ was measured in all six composting units in a period of two months (mid-November 2008 to mid-January 2009) with a passive sampling approach. The emission of $\mathrm{NH}_{3}$ was estimated by assuming that the (linear) relationship between the concentration inside the composting unit and emission of $\mathrm{NH}_{3}$ was the same as for $\mathrm{CO}_{2}$.

\subsection{Mass balancing}

MFA and SFA were performed by means of the mass-balance model STAN (version 2.0), which performs MFA according to the Austrian standard ÖNorm 2096 (Cencic and Rechberger, 2008). With STAN, the home composting system was built graphically (displayed as Sankey diagrams) by adding known mass flows, concentrations and transfer coefficients to the model. Simulations were performed to reconcile uncertain data and/or to compute unknown parameters. SFAs have been performed for VS, ash, C, N, K, P, Cd, $\mathrm{Cr}, \mathrm{Cu}$ and $\mathrm{Pb}$ (only the SFA of $\mathrm{C}$ is shown here). The uncertainty of concentrations in the waste input was inserted based on the standard deviation of the duplicate samples and the uncertainty of all outputs was assumed to be $2.5 \%$ for all parameters. The loss of material and compounds to the atmosphere during the composting process was estimated by STAN for VS, C, and N. Losses to the atmosphere of ash, K, P, Cd, Cr, Cu and $\mathrm{Pb}$ were assumed to be negligible and were set to zero in STAN.

\section{Results}

\subsection{OHW quantities and composition}

The amounts of waste added during one year to each of the composting units were 134$280 \mathrm{~kg}$ (see Table 1; the high amount of input waste in Unit 4 is due to the extended experimental period of increased $\mathrm{OHW}$ input). The composition of the input material is given in Table 2. The moisture content was in the range $64-79 \%$ and the organic content (VS) was $72-86 \%$ of TS. The $C$ and $\mathrm{N}$ content was $38-44 \%$ of TS and $1.6-1.9 \%$ of TS respectively, giving $\mathrm{C} / \mathrm{N}$ ratios of $21.7-24.7$. The concentrations of heavy metals and nutrients of the $\mathrm{OHW}$ were in the range of values given in the literature for $\mathrm{OHW}$ (Riber et al., 2007). 


\subsection{Chemical composition and quality of compost}

The composition of the compost from the six composting units is presented in Table 2 . The key parameters were moisture content (67-75\%), ash content (38-55\% of TS), C content (25-36 \% of TS) and N content (1.4-2.2 \% of TS). These parameters are all within the reported range for compost materials (Boldrin et al., 2010; last column of Table 2) however the moisture content is in the high end of the range. The heavy metal content was below all threshold limits. Table 4 shows a range of typical heavy metal contents in composts together with limit values for compost products in countries with strict quality guidelines (Hogg et al., 2002).

Table 4: Heavy metal limit values (in mg kg-1 TS) for selected EU countries (and European Commission) with strict compost qualities (Hogg et al., 2002). The heavy metal content of the home compost in this study, from Aarhus composting plant, Denmark (Andersen et al., 2010b) and from other typical composts from green waste as given by Hogg et al. (2002) and Whittle and Dyson (2002) are shown in the lower part of the table.

\begin{tabular}{|c|c|c|c|c|c|c|c|c|c|}
\hline & Regulation & Cd & $\mathrm{Cr}$ & $\mathrm{Cu}$ & $\mathrm{Hg}$ & $\mathrm{Ni}$ & $\mathbf{P b}$ & $\mathrm{Zn}$ & As \\
\hline \multirow[t]{2}{*}{ Austria } & $\begin{array}{l}\text { Compost ordinance: Quality } \\
\text { Class A+ (organic farming) }\end{array}$ & 0.7 & 70 & 70 & 0.4 & 25 & 45 & 200 & - \\
\hline & $\begin{array}{l}\text { Compost ordinance: Quality } \\
\text { Class A (agric.; hobby } \\
\text { gardening) }\end{array}$ & 1 & 70 & 150 & 0.7 & 60 & 120 & 500 & - \\
\hline Denmark & Compost after 1/6 2000 & 0.4 & 100 & 1000 & 0.8 & 30 & 120 & 4000 & - \\
\hline \multirow[t]{3}{*}{$\begin{array}{l}\text { European } \\
\text { Commission }\end{array}$} & $\begin{array}{l}\text { Draft W.D. Biological } \\
\text { treatment } \\
\text { of biowaste (class } 1 \text { ) }\end{array}$ & 0.7 & 100 & 100 & 0.5 & 50 & 100 & 200 & - \\
\hline & "ecolabel": 2001/688/EC & 1 & 100 & 100 & 1 & 50 & 100 & 300 & 10 \\
\hline & $\begin{array}{l}\text { “ecoagric" 2092/91EC } \\
\text { 1488/98EC }\end{array}$ & 0.7 & 70 & 70 & 0.4 & 25 & 45 & 200 & - \\
\hline Germany & Bio waste ordinance (I) & 1 & 70 & 70 & 0.7 & 35 & 100 & 300 & - \\
\hline \multirow[t]{2}{*}{ Netherlands } & Compost & 1 & 50 & 60 & 0.3 & 20 & 100 & 200 & 15 \\
\hline & Type of compost & $\mathrm{Cd}$ & $\mathrm{Cr}$ & $\mathrm{Cu}$ & $\mathrm{Hg}$ & $\mathrm{Ni}$ & $\mathbf{P b}$ & $\mathrm{Zn}$ & As \\
\hline \multirow[t]{2}{*}{ Denmark } & $\begin{array}{l}\text { Home compost (this study) } \\
\text { Unit 1-6 (range) }\end{array}$ & $\begin{array}{l}0.2- \\
0.4\end{array}$ & $\begin{array}{l}17- \\
45\end{array}$ & $\begin{array}{c}27- \\
60\end{array}$ & $\begin{array}{l}0.05- \\
0.26\end{array}$ & $\begin{array}{l}6- \\
8\end{array}$ & $\begin{array}{l}11- \\
22\end{array}$ & $\begin{array}{l}77- \\
109\end{array}$ & 2 \\
\hline & $\begin{array}{l}\text { Garden waste compost } \\
\text { (Andersen et al., 2010b) }\end{array}$ & 0.3 & 32 & 28 & 0.06 & 7 & 25 & 126 & - \\
\hline- & $\begin{array}{l}\text { Typical compost quality for } \\
\text { green waste (Hogg et al. } \\
\text { 2002) }\end{array}$ & 1.4 & 46 & 51 & 0.5 & 22 & 87 & 186 & - \\
\hline UK & $\begin{array}{l}\text { Green waste compost } \\
\text { (Whittle and Dyson 2002) }\end{array}$ & 1.5 & 3.7 & 16 & - & - & 6.8 & 108 & - \\
\hline
\end{tabular}

The quality of the final compost was assessed visually and from some of the key compositional parameters. In all cases the compost material had a nice dark colour and a pleasant smell. A common parameter that indicates that composting has been taking place is the $C / N$ ratio (Boldrin et al., 2010). The $C / N$ ratio decreased in all composting units 
during composting from 21.7-24.7 to 15.8-18.0. Table 2 shows the composition of the output material in Units 1 and 3 as well as the range of the composition from all six composting units. An example of the division between "fresh" and "mature" compost has been shown with data from Unit 3. The VS, C and N content all decrease significantly from "fresh" to "mature" compost which shows that degradation and stabilisation of organic matter is taking place.

\subsection{Leachate volume and quality}

The cumulative leachate generation over the two two-month sampling periods in Unit 1 are presented in Fig. 1. The volume of leachate increased linearly over time (with $\mathrm{R}^{2}$ correlations of 0.9984 and 0.9949 for the two periods respectively) and the two time series were very similar. In the first period (November-December 2008) the leachate generation was $3710 \mathrm{~mL}$ over 58 days $\left(64 \mathrm{~mL} \mathrm{day}^{-1}\right)$ and in the second period (March-April 2009) it was $3730 \mathrm{~mL}$ over 56 days $\left(67 \mathrm{~mL} \mathrm{day}^{-1}\right)$. The leachate generation has been averaged, extrapolated to the whole year of composting $(24 \mathrm{~L})$ and then divided by the entire input of waste (184 kg in Unit 1) to get a generation of $130 \mathrm{~L} \mathrm{Mg}^{-1}$ ww in Unit 1 (meaning a loss of $13 \%$ of the weight of the material through leachate). The losses of $\mathrm{C}$ and $\mathrm{N}$ via leachate during composting were $0.3-0.6 \%$ of the lost $\mathrm{C}$ and $1.3-3.0 \%$ of the lost $\mathrm{N}$ respectively (all leachate data are presented in Table 6 ). The amount and composition of leachate was assumed to be the same in all six composting units (as $\mathrm{L} \mathrm{Mg}^{-1} \mathrm{ww}$ ) due to lack of information on the leachate in Units 2-6, and the values from Unit 1 have therefore been used in the MFA for all composting units.

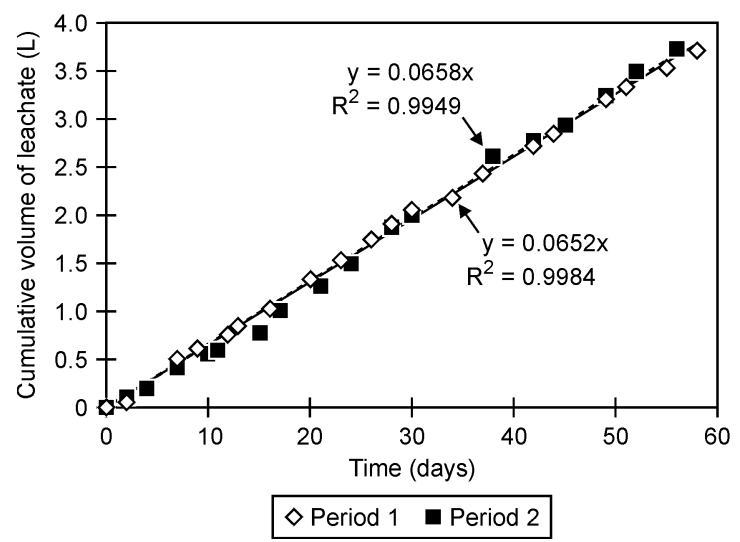

Figure 1: Leachate generation during the two two-month leachate sampling periods in Unit 1. Period 1 was November-December 2008 and period 2 was March-April 2009.

\subsection{Mass balances}

The MFA of Unit 1 is presented in Fig. 2 and the SFA of $C$ is presented in Fig. 3. During composting in the six composting units, 55-73\% of the material (including water) was lost to the atmosphere. The $\mathrm{C}$ loss was $63-77 \%$ and the $\mathrm{N}$ loss was $51-68 \%$. The loss of organic matter (VS) was measured as 66-79\%. The heavy metals and the nutrients (P and K) are all 
found mainly in the final compost. The concentrations of nutrients and heavy metals in the leachate were found to be very low.

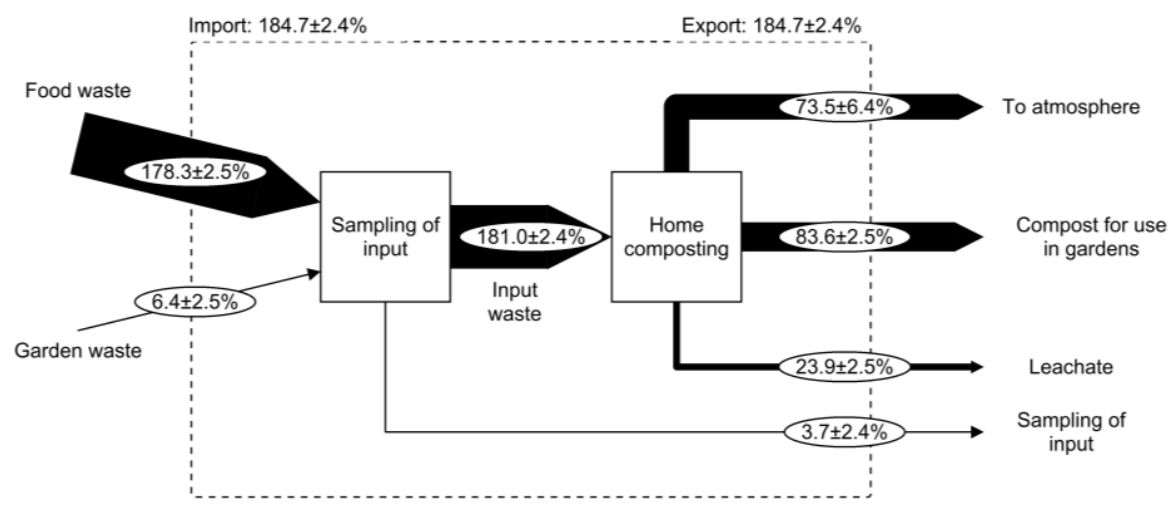

Home composting MFA, 2010

Flows [kg/a]

Figure 2: Material flow analysis of the home composting system in Unit 1. All numbers are in $\mathrm{kg}$ material $\mathrm{yr}^{-1}$ based on wet weight.

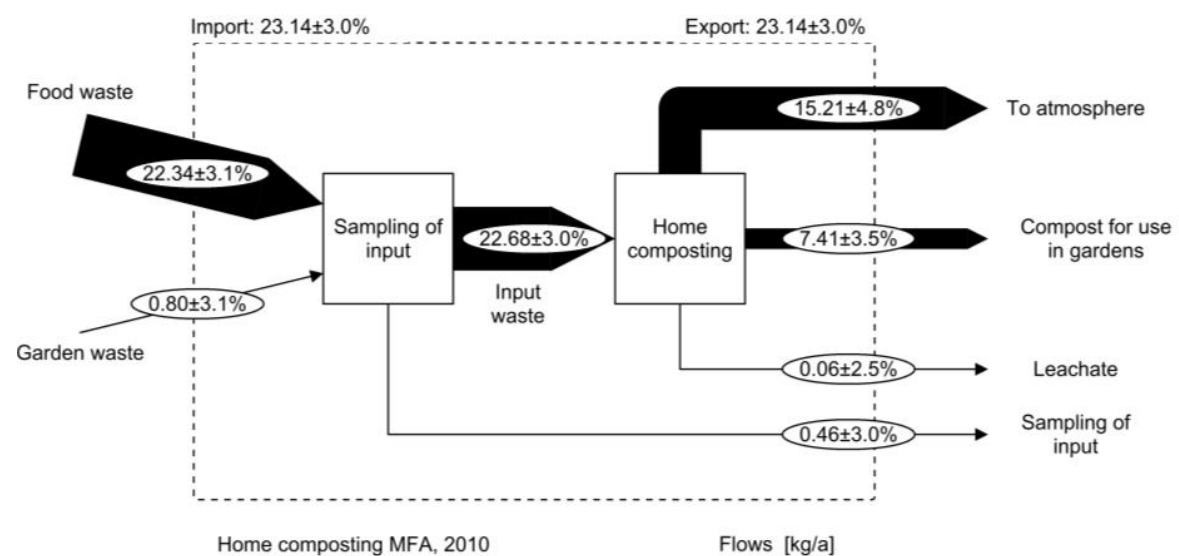

Figure 3: Substance (carbon) flow analysis of the home composting system in Unit 1. All numbers are in kg $\mathrm{C} \mathrm{yr}^{-1}$ based on dry weight.

\subsection{Gaseous emissions}

The gaseous emissions were measured as $177-252 \mathrm{~kg} \mathrm{CO}_{2} \mathrm{Mg}^{-1} \mathrm{ww}, 0.4-4.2 \mathrm{~kg} \mathrm{CH}_{4} \mathrm{Mg}^{-1}$ ww, 0.30-0.55 kg N $\mathrm{O} \mathrm{Mg}^{-1} \mathrm{ww}$, and 0.07-0.13 $\mathrm{kg} \mathrm{CO} \mathrm{Mg}^{-1} \mathrm{ww}$, according to Andersen et al. (2010a). The highest emissions were from the frequently mixed composting units (Units 1 and 2) while the lowest emissions were from the composting units that were not mixed at all (Units 5 and 6). By considering only $\mathrm{CH}_{4}$ and $\mathrm{N}_{2} \mathrm{O}$ the total global warming $\mathrm{EF}$ was calculated as $100-239 \mathrm{~kg} \mathrm{CO}$-eq. $\mathrm{Mg}^{-1} \mathrm{ww}$. The emissions have been related to the element mass basis to present the emissions as a percentage of the lost $\mathrm{C}$ and $\mathrm{N}$ respectively. The $\mathrm{CO}_{2}$ emissions were calculated as $51-95 \%, \mathrm{CH}_{4}$ as $0.3-3.9 \%$ and $\mathrm{CO}$ as 
0.04-0.08 \% of the degraded $\mathrm{C}$. The $\mathrm{N}_{2} \mathrm{O}$ emissions were 2.8-6.3 \% of the degraded $\mathrm{N}$ during composting. The data for each of the composting units are presented in Table 5.

$\mathrm{NH}_{3}$ emissions were estimated from the concentration measurements. The (linear) relationship between the concentration inside the composting unit and the emission of $\mathrm{CO}_{2}$ was reasonable $\left(\mathrm{R}^{2}\right.$ of 0.7214$)$. When assuming the same relationship for $\mathrm{NH}_{3}$, the estimated loss of $\mathrm{NH}_{3}$ was $0.03-2.0 \mathrm{~g} \mathrm{Mg}^{-1}$ ww or less than $0.004 \%$ of the lost nitrogen during composting in all composting units.

Table 5: Emissions of CO2, CH4, N2O and CO expressed in kg Mg-1 ww (as given in Andersen et al., 2010a) and as percent of total $\mathrm{C}$ and $\mathrm{N}$ emissions respectively, for home composting of organic kitchen waste (OHW) during 1 year.

\begin{tabular}{|c|c|c|c|c|c|c|c|c|}
\hline \multirow[b]{3}{*}{ Unit } & \multicolumn{8}{|c|}{ Gaseous emissions } \\
\hline & \multicolumn{4}{|c|}{$E F^{a}\left(k g ~ M g^{-1} w w\right)$} & \multicolumn{4}{|c|}{$\begin{array}{c}\text { Percent of total C } \\
\text { (or } \mathrm{N} \text { ) emissions (\%) }\end{array}$} \\
\hline & $\mathrm{CO}_{2}$ & $\mathrm{CH}_{4}$ & $\mathrm{~N}_{2} \mathrm{O}$ & $\mathrm{CO}$ & $\mathrm{CO}_{2}$ & $\mathrm{CH}_{4}$ & $\mathrm{~N}_{2} \mathrm{O}$ & CO \\
\hline 1 & 252 & 4.2 & 0.45 & 0.10 & 81 & 3.7 & 5.5 & 0.05 \\
\hline 2 & 240 & 3.7 & 0.39 & 0.09 & 92 & 3.9 & 4.6 & 0.06 \\
\hline 3 & 209 & 0.8 & 0.36 & 0.08 & 78 & 0.8 & 4.3 & 0.05 \\
\hline 4 & 236 & 1.0 & 0.55 & 0.13 & 95 & 1.1 & 6.3 & 0.08 \\
\hline 5 & 177 & 0.4 & 0.30 & 0.08 & 51 & 0.3 & 2.8 & 0.04 \\
\hline 6 & 189 & 0.6 & 0.32 & 0.07 & 83 & 0.7 & 5.1 & 0.05 \\
\hline \multicolumn{9}{|c|}{${ }^{\mathrm{a}} \mathrm{EF}$, emission factor } \\
\hline
\end{tabular}

\subsection{Life cycle inventory ( $\mathrm{LCl})$}

The full $\mathrm{LCl}$ is presented in Table 6. As mentioned previously, the main contributors to the $\mathrm{LCl}$ are gaseous emissions and loss of leachate. In addition to the reported emissions, other gases (such as volatile organic compounds), could be produced and emitted during composting, but these were thought to be of minor importance.

\section{Discussion}

\subsection{Compost}

The composition of the compost produced in the six composting units was similar to compositions reported previously in the literature (see Table 2). The moisture content seems to be a bit high, however (67-75 \%). Diaz et al. (2007) recommend that the moisture content is below $50 \%$ to keep the handling, transportation and application feasible. This is, however, not a major issue since the compost is used directly in the garden of the home composters. The compost material had a nice dark colour and a pleasant smell, which are generally associated with stability, maturity and a high concentration of organic matter (Diaz et al., 2007). The decrease in C/N ratio (21.7-24.7 to 15.8-18.0) also indicated that composting took place in the six composting units. 
Table 6: LCl data for home composting of organic household waste.

\begin{tabular}{|c|c|c|c|}
\hline & LCl data & Amount & Unit $^{\mathrm{a}}$ \\
\hline \multirow[t]{2}{*}{ Input waste } & Organic household waste & $113-273$ & kg ww $\mathrm{yr}^{-1}$ \\
\hline & Garden waste & $6-22$ & kg ww yr ${ }^{-1}$ \\
\hline \multirow{2}{*}{$\begin{array}{l}\text { Energy and materials } \\
\text { consumption }\end{array}$} & Electricity & 0 & $\mathrm{kWh} \mathrm{Mg}^{-1} \mathrm{WW}$ \\
\hline & Water & 0 & $\mathrm{LMg}^{-1} \mathrm{Ww}$ \\
\hline \multirow{9}{*}{$\begin{array}{l}\text { Gaseous emissions (to } \\
\text { atmosphere) }\end{array}$} & $\mathrm{CO}_{2}-\mathrm{C}$ (biogenic) & $177-252$ & $\mathrm{~kg} \mathrm{Mg}^{-1} \mathrm{ww}$ \\
\hline & & 51-95 & (\% of total C emitted) \\
\hline & $\mathrm{CH}_{4}-\mathrm{C}$ & $0.4-4.2$ & $\mathrm{~kg} \mathrm{Mg}^{-1} \mathrm{ww}$ \\
\hline & & $0.3-3.9$ & (\% of total $\mathrm{C}$ emitted) \\
\hline & $\mathrm{CO}-\mathrm{C}$ & $0.07-0.13$ & $\mathrm{~kg} \mathrm{Mg}^{-1} \mathrm{ww}$ \\
\hline & & $0.04-0.08$ & (\% of total $\mathrm{C}$ emitted) \\
\hline & $\mathrm{N}_{2} \mathrm{O}-\mathrm{N}$ & $0.30-0.55$ & $\mathrm{~kg} \mathrm{Mg}^{-1} \mathrm{ww}$ \\
\hline & & $2.8-6.3$ & (\% of total $\mathrm{N}$ emitted) \\
\hline & $\mathrm{NH}_{3}$ & $\sim 0$ & $\mathrm{~kg} \mathrm{Mg}^{-1} \mathrm{ww}$ \\
\hline \multirow{16}{*}{$\begin{array}{l}\text { Liquid emissions (to } \\
\text { groundwater) }\end{array}$} & Leachate & 130 & $\mathrm{~L} \mathrm{Mg}^{-1} \mathrm{wW}$ \\
\hline & $\mathrm{N}$ losses & 0.05 & $\mathrm{~kg} \mathrm{Mg}^{-1} \mathrm{ww}$ \\
\hline & & $0.3-0.6$ & (\% of total $\mathrm{N}$ emitted) \\
\hline & C losses & 0.33 & $\mathrm{~kg} \mathrm{Mg}^{-1} \mathrm{ww}$ \\
\hline & & $1.3-3.0$ & (\% of total $\mathrm{C}$ emitted) \\
\hline & BOD & 3.5 & $\mathrm{~kg} \mathrm{Mg}^{-1} \mathrm{ww}$ \\
\hline & $\mathrm{COD}$ & 9.9 & $\mathrm{~kg} \mathrm{Mg}^{-1} \mathrm{ww}$ \\
\hline & $\mathrm{K}$ & 6.4 & $\mathrm{~kg} \mathrm{Mg}^{-1} \mathrm{ww}$ \\
\hline & $\mathrm{P}$ & 0.08 & $\mathrm{~kg} \mathrm{Mg}^{-1} \mathrm{ww}$ \\
\hline & As & $2.4 \cdot 10^{-5}$ & $\mathrm{~kg} \mathrm{Mg}^{-1} \mathrm{ww}$ \\
\hline & $\mathrm{Cd}$ & $2.5 \cdot 10^{-6}$ & $\mathrm{~kg} \mathrm{Mg}^{-1} \mathrm{ww}$ \\
\hline & $\mathrm{Cr}$ & $3.2 \cdot 10^{-5}$ & $\mathrm{~kg} \mathrm{Mg}^{-1} \mathrm{ww}$ \\
\hline & $\mathrm{Cu}$ & $2.9 \cdot 10^{-4}$ & $\mathrm{~kg} \mathrm{Mg}^{-1} \mathrm{ww}$ \\
\hline & $\mathrm{Hg}$ & $2.8 \cdot 10^{-7}$ & $\mathrm{~kg} \mathrm{Mg}^{-1} \mathrm{ww}$ \\
\hline & $\mathrm{Ni}$ & $8.7 \cdot 10^{-5}$ & $\mathrm{~kg} \mathrm{Mg}^{-1} \mathrm{ww}$ \\
\hline & $\mathrm{Pb}$ & $9.9 \cdot 10^{-5}$ & $\mathrm{~kg} \mathrm{Mg}^{-1} \mathrm{ww}$ \\
\hline Finished product & Compost & $0.27-0.45$ & $\mathrm{~kg} \mathrm{Mg}^{-1} \mathrm{ww}$ \\
\hline
\end{tabular}

\subsection{C balance}

The $C$ balance was in all cases quite good and for all composting units the loss of $C$ to air was $63-77 \%$. The loss of $C$ via leachate was in all cases insignificant (0.3-0.6 \% of the lost C). This means that $23-37 \%$ of the $\mathrm{C}$ in the input material was left in the compost. The $\mathrm{CO}_{2}$ emissions were calculated as $51-95 \%, \mathrm{CH}_{4}$ as $0.3-3.9 \%$ and $\mathrm{CO}$ as $0.04-0.08 \%$ of the lost $\mathrm{C}$ (see Table 5). This means that in most cases the quantification of $C$ losses were in agreement with the $\mathrm{C}$ balance calculated in STAN and only a small fraction could not be accounted for. The loss of $\mathrm{CH}_{4}$ during composting is in line with experiments performed by 
Amlinger et al. (2008), in experiments with larger volume composting units $\left(0.8 \mathrm{~m}^{3}\right)$ and larger inputs of waste (up to $53 \mathrm{~kg}$ per week) (representing multi-family rather than singlefamily home composting). The $\mathrm{CH}_{4}$ loss was measured as 2.1-3.6\% of the total $\mathrm{C}$ emissions (Amlinger et al., 2008). The $\mathrm{CH}_{4}$ emissions are also in the same range as for centralized composting. Andersen et al. (2010c) reported $\mathrm{CH}_{4}$ emissions of $2.7 \pm 0.6 \%$ of the total $\mathrm{C}$ loss in a full-scale windrow composting system treating garden waste whereas Amlinger et al. (2008) reported $0.8-2.5 \%$ of the total C loss in a pilot-scale windrow composting system treating biowaste and garden waste.

\section{3. $\mathbf{N}$ balance}

The total $\mathrm{N}$ loss during composting was $51-68 \%$ and the $\mathrm{N}_{2} \mathrm{O}$ emissions constituted 2.8-6.3 $\%$ of these losses. $\mathrm{N}$ in leachate was in all cases insignificant (1.3-3.0 \% of the emitted $\mathrm{N}$ ). The $\mathrm{NH}_{3}$ emissions made up less than $0.004 \%$ of the total losses of $\mathrm{N}$ (in all composting units) according to the emission estimation. It should be stressed that this is a very rough estimate; however, the concentrations of $\mathrm{NH}_{3}$ in the composting units were in the ppbv level (2-121 ppbv), and the emissions were thus believed to be insignificant. According to Amlinger et al. (2008), $\mathrm{NH}_{3}$ was mostly emitted when the temperature was above $40-50^{\circ} \mathrm{C}$, the reason being twofold. Firstly, above $40^{\circ} \mathrm{C}$ nitrification of ammonium to $\mathrm{NO}_{2}^{-}$is inhibited (Stentiford \& de Bertoldi, 2010). Secondly, the dissociation constant (pKa) of $\mathrm{NH}_{4}{ }^{+}$decreases with increasing temperature, meaning that higher temperatures favour evaporation of $\mathrm{NH}_{3}$ (Boldrin et al., 2010). This could explain the very low emissions in the present study, where the temperature in compost rarely exceeded $25^{\circ} \mathrm{C}$ (Andersen et al., 2010a). The $\mathrm{NH}_{3}$ concentration measurements were performed over a period of two months, and it is therefore also assumed that this represents an average concentration of $\mathrm{NH}_{3}$ in the composting units during the composting process. The majority of the $\mathrm{N}$ lost during composting is assumed to be emitted as $N_{2}$, which is an environmentally unproblematic compound.

\subsection{Heavy metals}

The heavy metal balances could not be closed in all cases. In general the mass of heavy metals in the output was larger than in the input. The discrepancy between the input and output values might be related to the sampling technique. The input material was grab sampled from very small quantities and small errors in the sampling could potentially lead to large uncertainties, especially in the heavy metal concentrations. It is assumed that it is easier to represent compounds such as $\mathrm{C}$ and $\mathrm{N}$ in grab sampling, whereas trace compounds such as heavy metals are most likely distributed more unevenly in the input waste. In analyses of Danish household waste performed by Riber et al. (2007), a very high variance in a range of parameters in the fraction vegetable food was reported. It was concluded that the vegetable food waste could not be considered completely homogenous after the shredder treatment in this case, and this emphasizes that it is quite difficult to get representative samples of such heterogeneous material. The sampling of the output was done according to the theory of sampling, and is thus believed to better 
represent the final output material. According to the SFA of the heavy metals, most were found in the ash fraction (results not shown here). Boldrin and Christensen (2010) found, in a study on garden waste management in Denmark, that the heavy metals are correlated to the ash content, which indicates that most heavy metals are found in the mature compost. This is also supported by the very low concentrations of heavy metals in the leachate and the assumption that no heavy metals are lost as air emissions. The heavy metals can be considered to be unproblematic, due to very low concentrations in both compost and leachate.

\subsection{Leachate}

The volume of leachate collected in each of the two sampling periods (64-67 mL day ${ }^{-1}$ ) was similar to data reported elsewhere in the literature. In a study by Papadopoulos et al. (2009) the leachate quantity ranged from 2.1 to $3.2 \mathrm{~L}$ per composting cycle (five weeks), which is equivalent to $60-91 \mathrm{~mL} \mathrm{day}^{-1}$ in an experiment with daily inputs of $2.1-3.0 \mathrm{~kg}$ household waste person ${ }^{-1}$ day $^{-1}$ (of which $47 \%$ was organic waste). Amlinger et al. (2008) reported a leachate generation of $43-300 \mathrm{~mL} \mathrm{day}^{-1}$ in two differently managed home composting units. The relatively high generation might reflect that the addition of biowaste was very high (inputs of up to $53 \mathrm{~kg}$ per week). The leachate generation is equivalent to $130 \mathrm{~L} \mathrm{Mg}^{-1} \mathrm{ww}$ in this study, while the number was $31 \mathrm{~L} \mathrm{Mg}^{-1}$ ww and $270 \mathrm{~L}$ $\mathrm{Mg}^{-1}$ Ww in studies by Wheeler and Parfitt (2002) and Amlinger et al. (2008) respectively. The composition of the leachate was within normal values for leachates from composting of organic wastes (Table 3).

\section{6. $\mathrm{LCl}$}

The full $\mathrm{LCl}$ can stand as a platform for environmental assessments of single-family home composting systems. Here all relevant emissions need to be included in order to get a realistic picture of the environmental loads. Colón et al. (2010) have previously provided an $\mathrm{LCl}$ of home composting in Spain, where also the composting unit, the tools associated with the composting process (mixing tool, watering can etc.), water addition and electricity consumption were included. However, no leachate was recorded and the measurements of the gaseous emissions were estimated due to measuring equipment with too high detection limits. The study by Colón et al. (2010) was different in the sense that the input of waste was much higher (18 kg of waste per week on average) and the outside temperature was higher, which facilitates faster degradation of organic matter.

\section{Conclusion}

A life-cycle inventory was for the first time made for single-family home composting in Denmark. A comprehensive experimental setup with six home composting units was followed during one year and all contributions to environmental burdens were assessed. The composting units were fed with 2.6-3.5 kg organic household waste (OHW) per unit per week. The total loss of $\mathrm{C}$ during composting was $63-77 \%$ and of these losses, the $\mathrm{CO}_{2}$ and $\mathrm{CH}_{4}$ emissions made up 51-95 \% and 0.3-3.9\%, respectively. The $\mathrm{C}$ losses via leachate 
were insignificant (0.3-0.6 \% of the lost $\mathrm{C}$ ). The total $\mathrm{N}$ loss during the process was $51-68 \%$ and the $\mathrm{N}_{2} \mathrm{O}$ emissions constituted 2.8-6.3 \% of these losses. Ammonia $\left(\mathrm{NH}_{3}\right)$ losses were insignificant. The $\mathrm{N}$ in leachate was in all cases insignificant (1.3-3.0\% of the lost $\mathrm{N}$ ) and the remaining emissions were assumed to be gaseous $N_{2}$. The leachate generation was measured as $130 \mathrm{~L} \mathrm{Mg}^{-1} \mathrm{ww}$. The level of heavy metals in the final compost material was below all threshold values and the $\mathrm{C} / \mathrm{N}$ ratios were 15.8-18.0. In general the compost composition was considered to be within the ranges previously reported in literature and thus ready for application in private gardens. The $\mathrm{LCl}$ presented in this paper can be used as a starting point for making environmental assessments of single-family home composting systems. No major environmental problems were identified from home composting of OHW, except for the emissions of GHGs. In order to improve the environmental performance of the system, an effort should be made to decrease these emissions (for example by not so frequent mixing of the material).

\section{Acknowledgements}

The authors would like to thank the following voluntary waste suppliers (staff) from the Department of Environmental Engineering, Technical University of Denmark: Hans-Jørgen Albrechtsen, Julie Chambon, Charlotte Bettina Corfitzen, Ida Damgaard, Khara Deanne Grieger, Nanna Hartmann, Louise Hjelmar Krøjgaard, Laure Lopato, Gitte Bukh Pedersen, and Helle Ugilt $S \varnothing$. 


\section{References}

Amlinger, F., Peyr, S., Cuhls, C., 2008. Greenhouse gas emissions from composting and mechanical biological treatment. Waste Manag. Res. 26, 47-60.

Andersen, J.K., Boldrin, A., Christensen, T.H., Scheutz, C., 2010a. Greenhouse gas emissions from home composting of organic household waste. Waste Manag. 30, 24752482.

Andersen, J.K., Boldrin, A., Christensen, T.H., Scheutz, C., 2010b. Mass balances and lifecycle inventory for a garden waste windrow composting plant (Aarhus, Denmark). Waste Manag. Res. 28, 1010-1020.

Andersen, J.K., Boldrin, A., Samuelsson, J., Christensen, T.H., Scheutz, C., 2010c. Quantification of GHG emissions from windrow composting of garden waste. J. Environ. Qual. 39, 713-724.

Boldrin A., 2009. Environmental assessment of garden waste management. PhD Thesis, Department of Environmental Engineering, Technical University of Denmark, 2800 Kgs. Lyngby, Denmark.

Boldrin, A., Christensen, T.H., 2010. Seasonal generation and composition of garden waste in Aarhus (Denmark). Waste Manag. 30, 551-557.

Boldrin, A., Körner, I., Krogmann, U., Christensen, T.H., 2010. Composting: Mass balances and product quality. In Christensen, T.H. (Eds.), Solid Waste Technology \& Management, Chapter 9.3. John Wiley \& Sons, Ltd, Chicester (ISBN: 978-1-405-17517-3).

CEC, Council of the European Communities, 1999. Council Directive 1999/31/EC of 26 April 1999 on the landfill of waste. Official Journal of the European Communities No. L 182/119. Available at:

http://eur-lex.europa.eu/LexUriServ/LexUriServ.do?uri=OJ:L:1999:182:0001:0019:EN:PDF (verified June 2010).

Cencic, O., Rechberger, H., 2008. Material flow analysis with software STAN. J. Environ. Eng. Manag. 18, 3-7.

Christensen, T.H., Gentil, E., Boldrin, A., Larsen, A.W., Weidema, B.P., Hauschild, M., 2009. $C$ balance, carbon dioxide emissions and global warming potentials in LCA-modelling of waste management systems. Waste Manag. Res. 27, 707-715. 
Colón, J., Martínez-Blanco, J., Gabarell, X., Artola, A., Sánchez, A., Rieradevall, J, Font, X., 2010. Environmental assessment of home composting. Resour. Conserv. Recycl. 54, 893904.

Diaz, J.F., Bertoldi, M.D., Bidlingmeier, W., Stentiford, E., 2007. Compost science and technology. Waste Management Series 8, first edition. Elsevier, the Netherlands.

Fischer, K., 1996. Environmental impact of composting plants, in: Bertoldi, M.D., Sequi, P., Lemmes, B., Papi, T. (Eds.), The Science of Composting. Blackie Academic \& Professionals, Glasgow.

Gy, P., 1998. Sampling for Analytical Purposes. John Wiley \& Sons Ltd., Chichester, UK.

Hogg, D., Barth, J., Favoino, E., Centemero, M., Caimi, V., Amlinger, F., Devliegher, W., Brinton, W., Antler, S., 2002. Comparison of compost standards within the EU, North America and Australasia. Main report. The Waste and Resources Action Programme: http://www.compostingvermont.org/pdf/WRAP_Comparison_of_Compost_Standards_20 02.pdf (verified June 2010).

International Standards Organisation (ISO), 2006. ISO 14040, Environmental management - life cycle assessment - principles and framework. International Standards Organisation, Geneva, Switzerland. Reference number ISO 14040:2006(E).

Jasim, S., Smith, S.R., 2003. The practicability of home composting for the management of biodegradable domestic soild waste. Final report. Centre for Environmental Control and Waste Management, Department of Civil and Environmental Engineering, Imperial College, London.

Loll, U., 1994. Behandlung von Abwässern aus aeroben und anaeroben Verfahren zur biologischen Abfallbehandlung (Treatment of wastewater from aerobic and anaerobic biological waste treatment processes, in German). In: Wiemer, K., Kern, M. (Eds.) Verwertung Biologischer Abfälle. Witzenhausen, Germany: M.I.C. Baeza Verlag. pp. 281307.

Martínez-Blanco, J., Colón, J., Gabarrell, X., Font, X., Sánchez, A., Artola, A., Rieradevall, J., 2010. The use of life cycle assessment for the comparison of biowaste composting at home and full scale. Waste Manag. 30, 983-994.

Papadopoulos, A.E., Stylianou, M.A., Michalopoulos, C.P., Moustakas, K.G., Hapeshis, K.M, Vogiatzidaki, E.E.I., Loizidou, M.D., 2009. Performance of a new household composter during in-home testing. Waste Manag. 29, 204-213. 
Petersen, C., Kielland, M., 2003. Statistik for hjemmekompostering 2001 (Statistics for home-composting, in Danish). Miljøprojekt nr. 855, Miljøstyrelsen, Miljøministeriet. Last accessed April 2011 at:

http://www2.mst.dk/udgiv/publikationer/2003/87-7972-960-6/pdf/87-7972-961-4.pdf

Riber, C., Rodushkin, I., Spliid, H., Christensen, T.H., 2007. Method for fractional solidwaste sampling and chemical analysis. J. Environ. Anal. Chem. 87, 321-335.

Solomon, S., Qin, D., Manning, M., Alley, R.B., Berntsen, T., Bindoff, N.L., Chen, Z., Chidthaisong, A., Gregory, J.M., Hegerl, G.C., Heimann, M., Hewitson, B., Hoskins, B.J., Joos, F., Jouzel, J., Kattsov, V., Lohmann, U., Matsuno, T., Molina, M., Nicholls, N., Overpeck, J., Raga, G., Ramaswamy, V., Ren, J., Rusticucci, M., Somerville, R., Stocker, T.F., Whetton, P., Wood, R.A., Wratt, D. 2007. Technical summary. In: Climate change 2007: The physical science basis. Contribution of working group I to the fourth assessment report of the Intergovernmental Panel on Climate Change. [Solomon, S., Qin, D., Manning, M., Chen, Z., Marquis, M., Averyt, K.B., Tignor, M., Miller, H.L. (Eds.)]. Cambridge University Press, Cambridge, United Kingdom and New York, NY, USA.

Stentiford, E., de Bertoldi, M., 2010. Composting: process. In Christensen, T.H. (Eds.), Solid Waste Technology \& Management, Chapter 9.1. John Wiley \& Sons, Ltd, Chicester (ISBN: 978-1-405-17517-3).

Wheeler, P.A., Parfitt, J., 2002. Life cycle assessment of home composting. Proceedings of Waste 2002 Conference. Stratford, UK.

Wheeler, P.A., Parfitt, J., Ellis, J., Pratten, N., 1999. Life cycle impacts of home composting. Agency R\&D report reference no. CLO 329. AEA Technology, Harwell, Oxfordshire, UK.

Whittle, A.J., Dyson, A.J., 2002. The fate of heavy metals in green waste composting. The Environmentalist. 22, 13-21. 